E3S Web of Conferences 1, 11008 (2013)

DOI: $10.1051 / \mathrm{e} 3$ sconf/20130111008

(c) Owned by the authors, published by EDP Sciences, 2013

\title{
Heavy Metals in Commercial Fish from the Barents Sea (Winter 2011)
}

\author{
A. Y. Zhilin $^{1}$, N. F. Plotitsyna ${ }^{1}$ and A. M. Lapteva ${ }^{1}$ \\ ${ }^{1}$ Knipovich Polar Research Institute of Marine Fisheries and Oceanography (PINRO), 6 Knipovich St., 183038, \\ Murmansk, RUSSIA, zhilin@pinro.ru
}

\begin{abstract}
To assess the significance of metals in biota of the Barents Sea, preliminary information is presented on concentrations of $\mathrm{Cu}, \mathrm{Zn}, \mathrm{Ni}, \mathrm{Cr}, \mathrm{Mn}, \mathrm{Co}, \mathrm{Pb}, \mathrm{Fe}, \mathrm{Cd}$ and $\mathrm{As}$ in livers and muscle tissues of 3 commercial fish species collected in winter 2011. Generally, our results are within the reported literature range for regarding some commercially important species like cod and flounders indicating that metal levels are not elevated. The interspecific variability is not substantial; we only found significant difference for Fe concentrations for muscle, with the highest concentrations measured in long rough dab and the lowest in cod. To assess whether metal levels found in fish samples from the Barents Sea are safe for human consumption, a comparison is made to reference values for fish muscle and fish liver. Available data suggest that all muscle and liver of fish analysed in this study may be regarded as safe, since they are far below these thresholds.
\end{abstract}

Key words: Heavy metals, commercial fish, pollution monitoring

\section{Introduction}

Arctic aquatic environmental quality, and how humans may be affecting this, is an area which has received increasing attention in recent years. Marine organisms, among them fish, accumulate contaminants from the environment and therefore used in marine pollution monitoring programs to determine contaminant concentrations in order to assess the health risk for humans, and to use fish as environmental indicators of aquatic ecosystems quality (AMAP, 1998). Marine biologists have focused most of their attention on fisheries exploitation as the major factor affecting fish populations. However, other anthropogenic factors, such as marine pollution, play a major role in the decline of commercial marine fish species (Henry et al., 2004). The Barents Sea is an important area for commercial fisheries. Because potential contamination of fish with heavy metals might be crucial for the future exploitation of this resource, information on this issue is urgently needed. Hence, we provide preliminary data on selected metals in fish muscle and liver. A total of 22 fish specimens, representing different species from the Barents Sea, were analysed for the elements $\mathrm{Cu}, \mathrm{Zn}, \mathrm{Ni}, \mathrm{Cr}, \mathrm{Mn}, \mathrm{Co}, \mathrm{Pb}, \mathrm{Fe}$, Cd and As.

\section{Materials and Methods}

Fish samples were collected on cruise No. 81 of the PINRO research vessel «Fridtjof Nansen» to the Barents Sea in February 2011 using a commercial bottom trawl at 12 stations of the southern part of the Barents Sea (see Figure 1). On board ship, length and sexes of the fish were determined. Subsequently, the specimens were dissected and muscle tissues and livers were frozen individually at $-20^{\circ} \mathrm{C}$ in polyethylene containers. These samples were transferred to the PINRO laboratory of applied ecology and toxicology (accreditation in accordance with ISO/IEC 17025:2005, certificate № ROSS RU.0001.518450) for further analyses. Three species were selected for this study: haddock Melanogrammus aeglefinus, cod Gadus morhua, long rough dab Hippoglossoides platessoides. All reagents were of analytical grade. High purity water (redistiller BS) was used throughout. The stock solutions of metals $(1000 \mathrm{mg} / \mathrm{g})$ were obtained by dissolving the appropriate salts of the corresponding metals. Concentrated nitric acid $(70 \%)$ and were used to digest the samples. Certified reference materials (NBS DORM-2 and NBS DOLT-2, muscle and liver of dogfish Squalus acanthias, respectively) provided by the National Research Council of Canada was used to validate the method. These standards (in powder form) were prepared and analysed in the same manner as the samples. They were analysed at regular time intervals throughout the survey together with the field samples (see Table 1). The recoveries of 


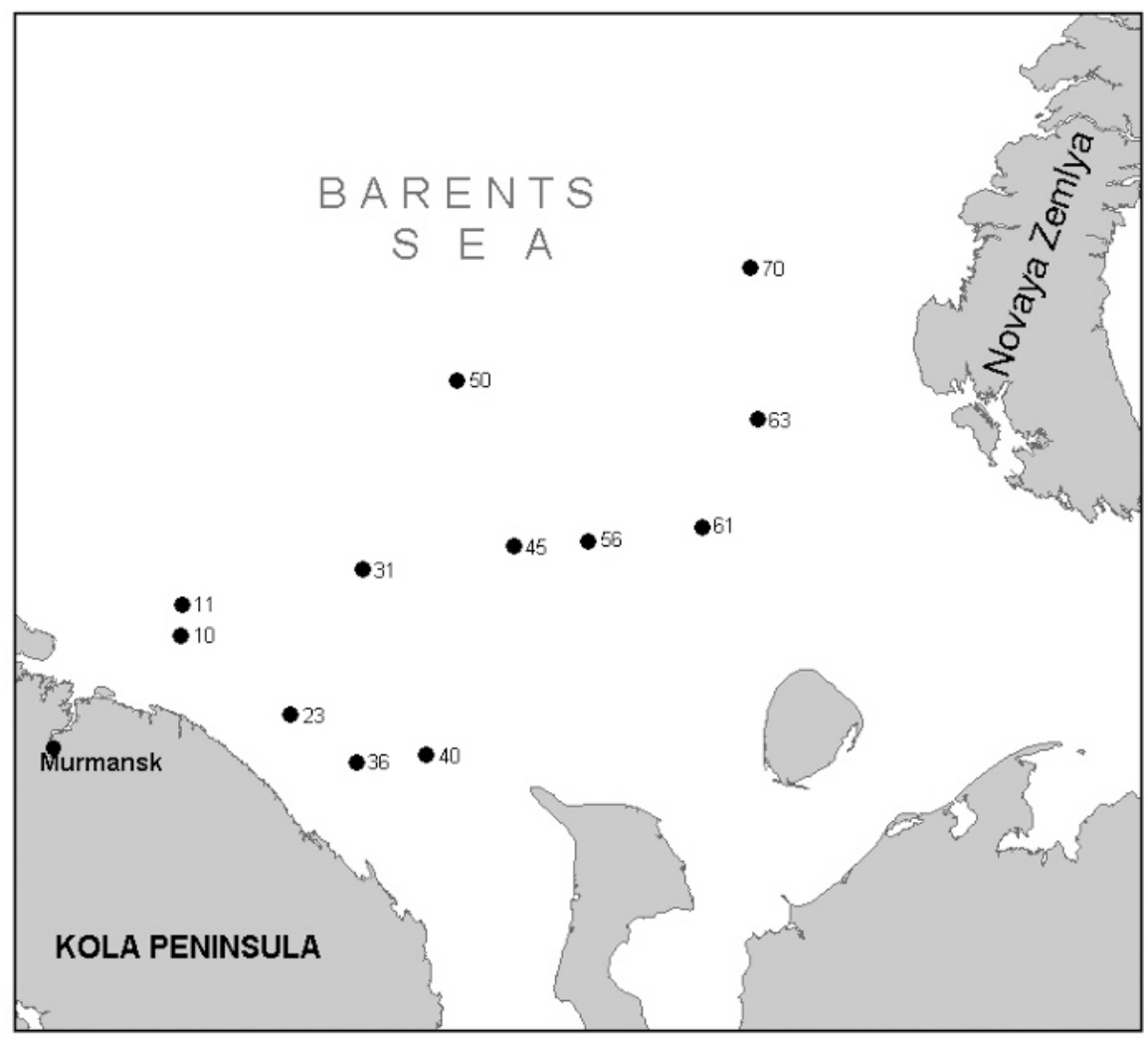

Fig. 1. Fish sampling locations along the Southern Part of the Barents Sea during 2011 winter season

Table 1. Verification of standard reference materials and instrumental detection limits in this study

\begin{tabular}{|c|c|c|c|c|c|c|}
\hline \multirow{2}{*}{ Element } & \multirow{2}{*}{$\mathrm{n}^{\mathrm{a}}$} & \multicolumn{2}{|c|}{ DORM-2 (muscle) } & \multicolumn{2}{|c|}{ DOLT-2 (liver) } & \multirow{2}{*}{$\begin{array}{c}\mathrm{IDL}^{\mathrm{c}} \\
(\mathrm{mg} / \mathrm{L})\end{array}$} \\
\hline & & Mean $\pm \mathrm{SD}^{b}$ & Certified value $^{b}$ & Mean $\pm \mathrm{SD}^{\mathrm{b}}$ & Certified value $^{b}$ & \\
\hline As & 4 & $18.8 \pm 1.0$ & $18.0 \pm 1.1$ & $16.4 \pm 0.9$ & $16.6 \pm 1.1$ & 0.001 \\
\hline $\mathrm{Cd}$ & 4 & $0.036 \pm 0.012$ & $0.043 \pm 0.008$ & $18.7 \pm 1.4$ & $20.8 \pm 0.5$ & 0.001 \\
\hline Co & 4 & $0.194 \pm 0.052$ & $0.182 \pm 0.031$ & $0.22 \pm 0.09$ & $0.24 \pm 0.05$ & 0.001 \\
\hline $\mathrm{Cr}$ & 4 & $36.1 \pm 6.2$ & $34.7 \pm 5.5$ & $0.39 \pm 0.12$ & $0.37 \pm 0.08$ & 0.001 \\
\hline $\mathrm{Cu}$ & 4 & $2.49 \pm 0.32$ & $2.34 \pm 0.16$ & $23.5 \pm 2.6$ & $25.8 \pm 1.1$ & 0.01 \\
\hline $\mathrm{Fe}$ & 4 & $159 \pm 12$ & $142 \pm 10$ & $1142 \pm 77$ & $1103 \pm 47$ & 0.01 \\
\hline $\mathrm{Pb}$ & 4 & $0.071 \pm 0.014$ & $0.065 \pm 0.007$ & $0.26 \pm 0.10$ & $0.22 \pm 0.02$ & 0.001 \\
\hline $\mathrm{Mn}$ & 4 & $3.34 \pm 0.60$ & $3.66 \pm 0.34$ & $5.58 \pm 0.19$ & $6.88 \pm 0.56$ & 0.001 \\
\hline $\mathrm{Ni}$ & 4 & $17.5 \pm 4.9$ & $19.4 \pm 3.1$ & $0.25 \pm 0.04$ & $0.20 \pm 0.02$ & 0.001 \\
\hline $\mathrm{Zn}$ & 4 & $26.2 \pm 4.4$ & $25.6 \pm 2.3$ & $88.0 \pm 3.5$ & $85.8 \pm 2.5$ & 0.001 \\
\hline
\end{tabular}

${ }^{\mathrm{b}}$ Unit: $\mathrm{mg} / \mathrm{kg}$ dry $\mathrm{wt} ;{ }^{\mathrm{a}} \mathrm{n}$ : sample size; ${ }^{\mathrm{c} I D L}$ : instrumental detection limits

the two SRMs were controlled within $100 \pm 20 \%$. The detection limits were determined by the mean and three times standard deviation of blank absorbance. Accordingly, the instrumental detection limits of samples for $\mathrm{Zn}, \mathrm{Ni}, \mathrm{Cr}, \mathrm{Mn}, \mathrm{Co}, \mathrm{Pb}, \mathrm{Cd}$ and As were $0.012 \mathrm{mg} / \mathrm{kg}$, and those of $\mathrm{Fe}$ and $\mathrm{Cu}$ were $0.12 \mathrm{mg} / \mathrm{kg}$, respectively. Fish samples were thawed at room temperature. Sample preparation and analysis were conducted according to the procedure described by Bernhard (Bernhard et al., 1976). Fish samples were homogenized in a blender and dissolved by microwave digestion (MS-6 Volta, Russia) using a system of rotors with six positions.

Approximately $500 \mathrm{mg}$ of dry sample was treated with a mixture 2:1 $\mathrm{HNO}_{3}: \mathrm{H}_{2} \mathrm{O}_{2}$ and samples were placed in a microwave $\left(1\right.$ hour at $\left.105{ }^{\circ} \mathrm{C}\right)$. After cooling, the entire resultant solution was quantitatively transferred to a $30 \mathrm{ml}$ volumetric flask, and the remainder made up to $30 \mathrm{ml}$ with ultrapure water. The elements were determined using a Flame $(\mathrm{Cu}, \mathrm{Zn}, \mathrm{Ni}, \mathrm{Cr}, \mathrm{Mn}, \mathrm{Co}, \mathrm{Pb}$ and $\mathrm{Fe}$ ) and Electrothermal ( $\mathrm{Cd}$ and $\mathrm{As})$ Atomic Absorption Spectrophotometry (AA-6800, Shimadzu Co. Ltd, Japan) equipped with background correction. The instrumental adjustments made were those recommended by the manufacturer's manual.

\section{Results and Discussion}

Our results on metals in fishes from the Barents Sea are compiled in Table 2 for muscle and in Table 3 for liver. $\mathrm{Ni}, \mathrm{Cd} \mathrm{и} \mathrm{Pb}$ concentrations are the on level limits of 
detection in each case, while for $\mathrm{Ni}$ this is only true for muscle. Low $\mathrm{Ni}, \mathrm{Cd}$ and $\mathrm{Pb}$ levels in fish muscle normally indicate that no artificial contamination has occurred. A substantial variability is noted for fish livers most probably due to the high fat content in this tissue. It is not possible, however, identify abnormally high levels in livers of both species; significantly elevated levels are only noted for As (Table 2, 3). Generally, $\mathrm{Cu}, \mathrm{Ni}, \mathrm{Cr}$ and Mn concentrations in muscle (Table 2) are distinctly lower than the liver values; only for $\mathrm{Zn}$ is the reverse true. Most of our results are within the range for Barents Sea ecosystem reported in the literature, which takes into account commercially important species (Zauke et al., 1999). There is so far no indication of elevated metal levels in main commercial fish species from the Barents Sea, despite the substantial anthropogenic pressure in that area (Stiansen and Filin, 2007). This view is supported by the literature data on trace metal concentrations in cod, which is the fish species most frequently used in biomonitoring of the Barents Sea and in long rough dab (Zauke et al., 1999). A detailed comparison of our results is possible to those of G.-P. Zauke (Zauke et al., 1999) who investigated a large number of fish species from the Barents Sea. Regarding fish species liver, reported data of 0.35-1.4 for $\mathrm{Cd} ;<0.3$ for $\mathrm{Pb} ;<0.1$ for $\mathrm{Ni} ; 12-27$ for $\mathrm{Cu}$ and $37-56$ for $\mathrm{Zn}(\mathrm{mg} / \mathrm{kg}$ dry wt.), after conversion to wet weight (dry wt/wet wt ratio of 1.9), generally are larger than our data given in Table 3. The somewhat different picture for metal concentrations in fish muscle (see Table 2) which generally are within the same range to be compared to the reported range of $<0.1$ for $\mathrm{Cd} ;<0.3$ for $\mathrm{Pb} ;<1.0$ for $\mathrm{Ni} ;<1.7$ for $\mathrm{Cu}$ and $15-19 \mathrm{Zn}(\mathrm{mg} / \mathrm{kg}$ wet $\mathrm{wt})$ (Zauke et al., 1999). The only exceptions are higher $\mathrm{Zn}$ levels shown up in our survey. It should be noted, however, that a substantial intraspecific heterogeneity has to be expected in both studies. Regarding fish livers, Cd levels in cod from the North Sea, for example, $0.08 \pm$ $0.06 \mathrm{mg} / \mathrm{kg}$ wet $\mathrm{wt}$, for plaice $0.12 \pm 0.09 \mathrm{mg} / \mathrm{kg}$ wet $\mathrm{wt}$ (Henry et al., 2004). Zauke et al. (Zauke et al., 1999) informs that cadmium concentrations in livers of cod and polar cod ranging from 0.07 to $0.47 \mathrm{mg} / \mathrm{kg}$ (wet wt), in specimens from the Irminger Basin. It is known that bioaccumulation of $\mathrm{Cd}$ may be accelerated by the higher soluble cadmium concentrations that normally occur in deeper waters, showing vertical profiles similar to those of nutrients (Zauke et al., 1999). The $\mathrm{Cu}$ and $\mathrm{Pb}$ levels detected in this study are also in good agreement with literature data. Mean $\mathrm{Cu}, \mathrm{Pb}$ levels in liver of cod have been found to be $9.1 \pm 3.8 \mathrm{mg} / \mathrm{kg}$ and $0.21 \pm 0.07 \mathrm{mg} / \mathrm{kg}$ (wet wt), in plaice $9.1 \pm 3.5 \mathrm{mg} / \mathrm{kg}$ and $0.38 \pm 0.28$ $\mathrm{mg} / \mathrm{kg}$ (wet wt) (Henry et al., 2004). To assess whether metal levels found in fish samples from the Barents Sea are safe for human consumption, a comparison is made to reference values for fish muscle. The range of such values proposed and issued in some European countries is rather narrow, yielding $0.2 \mathrm{mg} / \mathrm{kg}$ for $\mathrm{Cd} ; 1.0 \mathrm{mg} / \mathrm{kg}$ for $\mathrm{Pb} ; 5.0 \mathrm{mg} / \mathrm{kg}$ for As (wet wt) in Russia (SanPin, 2002); $0.10 \mathrm{mg} / \mathrm{kg}$ for $\mathrm{Cd} ; 0.50 \mathrm{mg} / \mathrm{kg}$ for $\mathrm{Pb}$ (wet wt) in Germany (BgVV, 1997) and $0.2 \mathrm{mg} / \mathrm{kg}$ for $\mathrm{Pb}, 0.05$ $\mathrm{mg} / \mathrm{kg}$ for $\mathrm{Cd}$ in $\mathrm{EC}$ (muscle tissue, wet wt) (EC, 2001). Available data suggest that all fish muscle analysed in this study (Table 2) may be regarded as safe, since they are far below these thresholds. Although fish muscle is the most important part to be used for human consumption, fish liver may also be consumed to some extent. Cod liver, for example, is commercially used for the production of fish oil. Furthermore, fish liver may serve as an additional valuable source of protein, vitamin $\mathrm{A}$ and vitamin $\mathrm{C}$ in the traditional food of people of the Russia, calling for an assessment of contaminants. Russian limits for fish liver, for example, are $0.7 \mathrm{mg} / \mathrm{kg}$ for $\mathrm{Cd} ; 1.0 \mathrm{mg} / \mathrm{kg}$ for $\mathrm{Pb}$ (wet wt) (SanPin, 2002). The cadmium and lead values reported in this study for all of the species investigated (Table 3) not may be of any concern, if people are consuming them. This applies to livers of haddock $(0.09$ and $0.49 \mathrm{mg} / \mathrm{kg}$ wet wt, respectively), and particularly to liver of cod ( 0.14 and $0.56 \mathrm{mg} / \mathrm{kg}$ wet $\mathrm{wt}$, respectively), which is used more frequently for human consumption.

Table 2. Metal concentrations ( $\mathrm{mg} / \mathrm{kg}$ wet wt) in muscle tissues of haddock Melanogrammus aeglefinus (Had), cod Gadus morhua (Cod), long rough dab Hippoglossoides platessoides (Lrd) from Barents Sea in 2011

\begin{tabular}{lcccccccccc}
\hline Sample & $\mathrm{Cu}$ & $\mathrm{Zn}$ & $\mathrm{Ni}$ & $\mathrm{Cr}$ & $\mathrm{Mn}$ & $\mathrm{Co}$ & $\mathrm{Pb}$ & $\mathrm{Fe}$ & $\mathrm{Cd}$ & $\mathrm{As}$ \\
\hline $\mathrm{Had}^{\mathrm{a}}$ & $0.58 \pm 0.10$ & $5.25 \pm 1.93$ & $0.39 \pm 0.13$ & $0.91 \pm 0.57$ & $0.17 \pm 0.05$ & $0.23 \pm 0.13$ & $0.40 \pm 0.09$ & $12.2 \pm 9.35$ & $0.03 \pm 0.01$ & $8.23 \pm 2.72$ \\
$\mathrm{Cod}^{\mathrm{b}}$ & $0.59 \pm 0.21$ & $4.41 \pm 0.59$ & $0.24 \pm 0.07$ & $0.90 \pm 0.25$ & $0.16 \pm 0.04$ & $0.65 \pm 0.21$ & $0.21 \pm 0.13$ & $7.15 \pm 5.39$ & $0.02 \pm 0.01$ & $6.70 \pm 2.68$ \\
$\mathrm{Lrd}^{\mathrm{c}}$ & $0.51 \pm 0.01$ & $5.03 \pm 0.15$ & $0.23 \pm 0.08$ & $0.73 \pm 0.29$ & $0.22 \pm 0.02$ & $1.03 \pm 0.09$ & $0.24 \pm 0.19$ & $49.9 \pm 80.8$ & $0.01 \pm 0.01$ & $7.83 \pm 2.03$
\end{tabular}

${ }^{\mathrm{a}} \mathrm{Had}$ : number of samples $-8 ;{ }^{b} \mathrm{Cod}$ : number of samples $-10 ;{ }^{c} \mathrm{Lrd}$ : number of samples -4

Table 3. Metal concentrations ( $\mathrm{mg} / \mathrm{kg}$ wet wt) in liver tissues of haddock Melanogrammus aeglefinus (Had), cod Gadus morhua (Cod) from Barents Sea in 2011

\begin{tabular}{lcccccccccc}
\hline Sample & $\mathrm{Cu}$ & $\mathrm{Zn}$ & $\mathrm{Ni}$ & $\mathrm{Cr}$ & $\mathrm{Mn}$ & $\mathrm{Co}$ & $\mathrm{Pb}$ & $\mathrm{Fe}$ & $\mathrm{Cd}$ & $\mathrm{As}$ \\
\hline $\mathrm{Had}^{\mathrm{a}}$ & $8.98 \pm 2.86$ & $4.50 \pm 0.77$ & $5.33 \pm 0.45$ & $1.33 \pm 0.74$ & $1.07 \pm 0.13$ & $1.03 \pm 0.67$ & $0.49 \pm 0.26$ & $52.3 \pm 42.4$ & $0.09 \pm 0.09$ & $15.6 \pm 7.62$ \\
$\mathrm{Cod}^{\mathrm{b}}$ & $9.26 \pm 3.66$ & $4.33 \pm 1.59$ & $5.72 \pm 0.35$ & $1.99 \pm 0.60$ & $1.37 \pm 0.17$ & $1.93 \pm 0.35$ & $0.56 \pm 0.27$ & $33.3 \pm 41.0$ & $0.14 \pm 0.15$ & $11.3 \pm 7.38$
\end{tabular}

${ }^{\mathrm{a}} \mathrm{Had}$ : number of samples $-8 ;{ }^{\mathrm{b}} \mathrm{Cod}$ : number of samples -10 
Although metal contents in fish are usually specific to a species (Henry et al., 2004), no significant variations of the metal concentrations are observed in the liver between the studied species. In contrast, for muscle, we only found significant difference for Fe concentrations, with the highest concentrations measured in long rough dab (blood line Pleuronectidae) and the lowest in cod. Differences in metal concentration between species may be related to habitat, fish mobility, diet, or to other characteristic behaviour. Flounders live in close association with sediments in which they bury and from where they mainly feed. This species seems to be the most appropriate fish for contaminant-monitoring purposes (Henry et al., 2004). Cod is a demersal fish, whose diet consists of pelagic and benthic organisms and is less exposed to eventually sediment-associated contamination than flounder. As in other studies, we observed higher levels of metals in liver than in the muscle tissues. The differences in concentration of magnitude originate from differences in physiological functions of muscle and liver. Thus, the liver is often recommended as a target tissue when monitoring metal concentrations in aquatic environments. Pollutants may enter the water system via deposition of atmospheric emissions and direct run-off from local sources. According to the AMAP (AMAP, 1998) report, the main source of industrial dust is the steel metallurgy plant at Nikel on the Kola Peninsula. Despite the high activity of this source of pollution the results of the present study indicate no evidence of appreciable pollution of the Barents Sea. Metal concentrations in fish collected from this area are similar to those reported by previous studies (Jakobsen and Ozhigin, 2011).

\section{Conclusion}

This study was carried out to provide information on heavy metal concentrations of muscle and liver tissue in fish from the Barents Sea. All results were well below the limits for fish proposed by national and European standards. Fish resources of the Barents Sea, which are in constant exposure to low heavy metal concentrations in the marine habitat, not may be at risk in the short term. But more in-depth studies and heavy metals monitoring of biota of the Barents Sea should be conducted in order the safeguard the marine environment and save public health in the long term.

\section{Acknowledgements}

This work carried out as part of state monitoring of aquatic biological resources and their habitat through the Russian Federal Agency for Fisheries. We would like to express our sincerest gratitude to all who have assisted and supported this study.

\section{References}

AMAP. AMAP assessment report: Arctic pollution issues. Arctic Monitoring and Assessment Programme (AMAP), Oslo, 1998. 859 pp.

Bernhard M. Manual of methods in aquatic environment research, part 3: sampling and analyses of biological material. FAO Fish Tech Paper 158, UNEP Rome. 1976.

Henry F, Amara R, Courcot L, Lacouture D, Bertho ML. Heavy metals in four fish species from the French coast of the Eastern English Channel and Southern Bight of the North Sea. Environ Int 2004; 30(5): 675-683.

Mart L, Rützel H, Klahre P, Sipos L, Platzek U, Valenta $P$, Nürnberg HW. Comparative studies on the distribution of heavy metals in the oceans and coastal waters. Sci Total Environ 1982; 26: 1-17.

Stiansen JE, Filin AA (Eds). Joint PINRO/IMR report on the state of the Barents Sea ecosystem 2006, with expected situation and considerations for management. IMR/PINRO Joint Report Series. 2007;2: 172-173.

Zauke GP, Savinov VM, Ritterhoff J, Savinova T. Heavy metals in fish from the Barents Sea (summer 1994). Sci Total Environ 1999;227:161-73.

SanPin. Hygienic requirements for safety and nutrition value of food products, sanitary and epidemiological rules and regulations (SanPin 2.3.2.1078-01) (in Russian). State system of sanitary-epidemiological regulations of the Russian Federation, Moscow, 2002.

BgVV. Bekanntmachungen des Bundesinstituts für gesundtheitlichen Verbraucherschutz und Veterinärmedizin (BgVV): Richtwerte für Schadstoffe in Lebensmitteln. Bundesgesundhbl. 1997;5: 182-184.

EC. Commission Regulation (EC) no 466/2001 of 8 March 2001. Official Journal of European Communities 1.77/1. 2001.

Jakobsen T, Ozhigin V (Eds). The Barents Sea ecosystem, resources, management. Half a century of Russian-Norwegian cooperation. Tapir Academic press. Trondheim. 2011. $832 \mathrm{pp}$. 